\title{
WPS3255
}

\section{Trade, Regulations, and Growth}

\author{
Bineswaree Bolaky \\ University of Maryland
}

\author{
Caroline Freund* \\ The World Bank
}

March 2004

\begin{abstract}
Trade does not stimulate growth in economies with excessive regulation. We examine the effect of openness on growth using cross-country regressions on data from more than 100 countries. Results from levels regressions imply that increased openness is, if anything, associated with a lower standard of living in heavily-regulated economies. Growth regressions confirm that the effect of increased trade on growth is absent in highly regulated countries. Once we control for the effect of domestic regulation, the evidence that trade positively affects growth is stronger than has been found in previous studies. Excessive regulations restrict growth because resources are prevented from moving into the most productive sectors and to the most efficient firms within sectors. In addition, in highly regulated economies, increased trade is more likely to occur in the wrong goods-i.e. goods where comparative advantage does not lie. The results imply that regulatory reform enhances the benefits of trade liberalization.
\end{abstract}

* We are grateful to Mary Amiti, Simeon Djankov, Jose Garcia-Montalvo, Hiau Looi Kee, Aart Kraay, Daniel Lederman, Philip Levy, Marcelo Olarreaga and participants at the World Bank seminar for comments on an earlier draft. Correspondence: The World Bank, 1818 H Street, NW, Washington DC, 20433, email:

cfreund@worldbank.org, tel: 202-473-7102. 


\section{Introduction}

There is some evidence that trade leads to faster income growth. The intuition is that openness enhances specialization, raising the level of income. Specialization also improves the return on investment, which stimulates growth. In addition, there is increasing evidence that trade fosters productivity growth within industries, forcing bad firms to exit and allowing good firms to expand. But trade cannot induce specialization or discipline firms if factor movement is restricted. In many economies, strict regulations prevent some firms from entering, others from exiting, and labor from moving across sectors or across firms. In these countries, trade may be less able to serve as a force of growth. The logic is simple: if the structure of economic activity is rigid, then trade only has a modest impact on the allocation of resources across and within industries. Moreover, to the extent that production structure does change, excessive regulation may encourage increased production of the wrong goods-goods the country is not relatively efficient at producing.

Alternatively, it is possible that trade forces countries to ease regulations. Trade will increase the costs of excessive regulation and could lead domestic and foreign investors to pressure the government to improve institutions. Indeed, there is some evidence that increased trade reduces corruption (Ades and Di Tella 1999). Trade could therefore have a stronger effect on growth in countries with bad institutions since it could both encourage regulatory reform and lead to more specialization.

In this paper, we examine whether the effect of trade on growth is dependent on the regulatory environment. We find strong evidence that increased trade does not stimulate growth in economies with high regulation, and some evidence that trade may even hamper growth in those with excessive regulation. Our results imply that any beneficial effect of trade on 
institutions does not compensate for the damage that a poor regulatory structure does to generating growth through trade. The implication for policy sequencing is that the countries that place an excessive regulatory burden on the private sector must have a strategy in place to improve their business climate before (or at least contemporaneously with) undertaking trade reform.

Our work contributes to a growing literature on the importance of trade and institutions in growth. Variables representing both institutions and openness have been shown to be highly significant in cross-country growth regressions, and there is evidence that causality runs from institutional quality and trade to growth. Acemoglu, Johnson, and Robinson (2000) show that institutions instrumented by settler mortality rates have large effects on income levels. Frankel and Romer (1999) show that openness instrumented by distance has significant effects on growth.

There is an ongoing debate about which of the two-institutions or openness-is more important for growth. Using different methodologies, Rodrik, Subramanian, and Trebbi (2002) and Dollar and Kraay (2002) run a horse race between institutions and trade. Results from the former suggest that institutions matter more for growth in the very long run, while results from the latter imply that trade is more important for medium-term growth. Dollar and Kraay (2003), however, argue that independent effects of trade and institutions are impossible to identify in the long run because their underlying determinants are the same.

We focus on the interaction between the two, as opposed to evaluating the direct contributions of trade and institutions to growth. We find that trade is not good for growth in highly regulated countries, as measured by regulation on entry and labor. Our results imply that 
there is a primacy of institutions over trade in the most distorted economies - not only do bad institutions lower growth, but they also prevent trade from generating growth.

The paper is organized as follows. The next section surveys evidence on trade and growth and how regulations affect structural change following liberalization. Section III describes the data. Section IV and V present the cross-section levels and growth results, respectively. Section VI concludes.

\section{The Evidence on Trade, Growth, and Structural Change}

There is a large literature on the effect of openness on growth. The general conclusion is that impediments to trade lower growth (Dollar 1992, Ben-David 1993, Sachs and Warner 1995, and Frankel and Romer 1999). Rodriguez and Rodrik (1999), however, argue that the measures of openness used are poor measures of trade barriers or are highly correlated with other sources of bad performance. For example, they show that the results on openness and growth are not robust when controlling for other determinants of income. But, since the number of observations is limited, the Rodriguez-Rodrik (1999) results also have a shortcoming; there are too many highly-correlated explanatory variables in their regression, making it impossible to identify the separate effect of trade on growth.

There are alternative ways of looking for evidence that trade promotes growth. Since the gains are theorized to come through specialization, we would hope to see evidence that sectoral output and employment are influenced by the level of openness. While there is evidence that comparative advantage guides specialization, the evidence that the degree of specialization is influenced by openness is weak. Using data on production patterns in 20 OECD countries since 1970, Redding (2002) finds that world prices have been a major driver of specialization, but that 
specialization does not tend to increase over time. Wacziarg and Wallack (2003) find little evidence that labor turnover increases following trade liberalization, using data from 25 episodes of trade liberalization. The countries in their sample, however, tend to be ones with excessive regulations, such as Argentina and Bolivia, and they do find increases when reform is broader and includes deregulation and privatization. Other related work also offers only modest evidence of significant labor reallocation as openness increases in developing countries (see, for example, Papageorgiou et. al. 1991, Revenga 1997, Currie and Harrison 1997, Roberts and Tybout 1996). The fact that trade reform does not affect employment in developing countries is often attributed to excessive labor regulations. Indeed, Blanchard and Portugal (2001) show that employment protection has strong negative effects on the reallocation of labor. This suggests that trade will have a lower effect on growth in economies with rigid labor laws.

The micro evidence that trade promotes an intra-sectoral reallocation of resources is stronger. Firm heterogeneity and a wide dispersion of productivity levels are well documented within industries; as a result, exit is necessary to rid the sector of low productivity firms and entry is important to enable the arrival of new industry leaders. Roberts and Tybout (1996) find that about 80 percent of employment reallocation in a handful of semi-industrialized countries occurs within rather than across four-digit ISIC industries. They also find that productivity dispersion tends to be relatively greater in industries not exposed to foreign competition, and that productivity growth is higher in tradable products. This implies that foreign competition serves as a disciplining device within industries. Bernard and Jensen (1999) use plant level data from the United States and show that the effect of reallocation on productivity is quite large, making up over $40 \%$ of total factor productivity growth in the manufacturing sector. They also find that reallocation to exporting firms is important in generating growth effects. Pavcnik (2002) finds 
that a reshuffling of resources and output to the more efficient producers was largely responsible for aggregate productivity growth in Chile following trade liberalization. She concludes that "barriers to plant turnover are important determinants of the success of trade liberalization." In a survey of studies of transition economies, Djankov and Murrell (2003) find that productivity is enhanced by import competition in Eastern European countries, but is in general reduced by import competition in the former Soviet Union-where business regulations tend to be more burdensome. The results are consistent with the hypothesis that trade promotes growth only in the presence of benign regulation on factor movements.

In sum, these results imply that cross-country studies of trade and growth will suffer a bias since they do not control for the regulatory regime. This paper provides a remedy by allowing the elasticity of trade to growth to be different in highly regulated economies. Most importantly, this allows us to determine whether the regulatory environment matters for trade to have positive effects on growth.

\section{Data}

The dependent variable is income. We use the level and average growth of real per capita income at PPP. For the levels regressions, per capita income is measured as the log-level of per capita GDP at constant 1996 dollars in PPP terms for the year 2000, from the Summers-Heston dataset version 6.1. For the growth regressions we use average growth in real income during the 1990s, from the same dataset. It is standard practice to use PPP-adjusted GDP because it more accurately captures the standard of living across different countries, and is not subject to large reorderings in rank as a result of exchange rate fluctuations. 
Our index of regulations is composed of data on labor regulations and business entry regulations drawn from the "Doing Business" dataset of the World Bank. Data are available for a list of 133 countries benchmarked at January 2003. While some business and labor regulations may be necessary to protect consumers and workers, evidence implies that too much regulation is inefficient and harms the very groups it claims to protect. Djankov et al. (2002) find that countries with more restrictive entry procedures have higher corruption and larger unofficial economies, but not better quality public or private goods. Botero et. al. (2003) show that countries with more restrictive labor laws have a larger unofficial economy, lower labor force participation, and higher unemployment, especially of women and young adults.

These measures of entry and labor regulations also have been shown to have large effects on industrial structure and adjustment. Fisman and Sarria-Allende (2004) find that in countries with excessive regulations, industries respond to shocks to growth opportunities through the expansion of existing firms, while in countries with low barriers to entry, industries respond through the creation of new firms. Moreover, in countries with high entry barriers, industries characterized by large turnover tend to have only a few large firms while countries with low barriers have many smaller firms. Klapper, Laeven, and Rajan (2003) use data on firms in Western and Eastern Europe and find that entry regulations lead to less entry, especially in industries with naturally high entry. They also find less entry into labor-intensive industries in countries with excessive labor regulations.

The labor regulations index consists of the logarithm of an employment laws index, where the latter reflects how regulated the labor market is and is constructed through an examination of detailed provisions in the labor laws of each country. The employment laws index is an average of three indices covering flexibility of hiring, conditions of employment and 
flexibility of firing. ${ }^{1}$ The natural logarithm of the index of labor regulations ranges in value from 3.66 to 4.09 in the sample of 108 countries that we use. Next we develop an index of entry regulations, using data on the number of procedures and the time it takes to start a business in each country. We take the logarithm of an equally-weighted average of the data from both sets of entry regulations (number of procedures and days) after rescaling each dataset series. The final range of values for the natural log of the constructed entry regulation index is 3.71 to 4.12 . We then average the index of labor regulations and the index of entry regulations, with final values of the regulation index ranging from 3.71 to 4.09 . The index of regulations is constructed such that higher values reflect a greater degree of regulation both in the labor market and the business sector.

Appendix Table A4 shows the mean of the regulation index for various income groups and regions. While high income countries do tend to have less regulation, the index is not monotonically increasing in income. Low- and middle-income countries tend to have roughly the same level of regulation on average. Regional differences are more acute. Latin America and the Caribbean is the most regulated region, North America is the least regulated region. United States, Denmark, New Zealand, Canada, and Hong Kong are the five least regulated countries. Brazil, Belarus, Mozmbique, Venezuela, and Paraguay are the five most regulated.

We use two measures of trade openness. The first is a measure of current total trade relative to current GDP in local currency. The second is a PPP-adjusted measure that uses 2000 trade data (exports and imports at current dollars) from the WDI and is then deflated to be

\footnotetext{
${ }^{1}$ The raw data we have from the Doing Business database for the labor and entry components are rescaled such that their mean values are 50 and standard deviation 5. The final series range in value from 39 to 60 for the employment laws index, from 38.36 to 62.34 for the number of entry procedures and 43.26 to 69.20 for the number of days it takes to start a new business over the sample of 108 countries used in our regression analysis.
} 
expressed in terms of 1996 dollars. ${ }^{2}$ We then divide it by 2000 GDP at PPP at constant 1996 dollars. ${ }^{3}$ The log of these ratios are then used as our measures for trade openness.

We use a rule-of-law index that is constructed by Kaufmann, Kraay and Zoido-Lobaton (2002) for the period 2000-01 and taken from the Dollar and Kraay dataset. The index is constructed for 175 countries. It is constructed from indicators reflecting "the extent to which agents have confidence in and abide by the rules of society. These include perceptions of the incidence of both violent and non-violent crime, the effectiveness and predictability of the judiciary, and the enforceability of contracts" (Kaufmann, Kraay, and Zoido-Lobaton (2002), page 8$)$.

We add as explanatory variables in the regression the natural logarithm of population as a proxy for market size, with data taken from the WDI. In addition we have a dummy variable for countries that are land-locked and a variable on the distance of these countries from the equator, measured as absolute value of latitude of the country's capital city. Both are taken from the Dollar and Kraay dataset (2002). We also use data on the legal origin of countries as well as data on their proportions of English and European-languages speakers, drawn from Doing Business dataset and Dollar and Kraay, respectively. We start with the Doing Business dataset of 133 countries and delete those countries for which data are not available for our explanatory variables. $^{4}$ This leaves us with a maximum of 108 countries in the levels regressions, listed in the Appendix (Table A1).

\footnotetext{
${ }^{2}$ We deflate the data using the US GDP deflator for years 1996 and 2000. Dollar and Kraay in their dataset construct their log trade openness measure in a different way. They deflate the trade data at constant $1995 \$$ by 1.4636 (the cumulative growth of US GDP deflator for the period 1985-1995). They then divide it by real GDP at PPP at constant 1985 dollars and take the natural logarithm of that ratio.

${ }^{3}$ This is constructed by adding our figures for the log-real per capita GDP at PPP at constant 1996 dollars for year 2000 from the Summers-Heston dataset with the logarithm of population at 2000 from WDI.

${ }^{4}$ We had to delete countries for which there were no data on entry and labor regulations indices, current trade to GDP or PPP per capita real income from the Summers-Heston dataset among others.
} 
We construct a dummy variable for the log-level of the regulation index that takes a value of 1 for the one-quarter and subsequently one-third most heavily regulated countries and zero otherwise.

\section{Cross-Section Analysis}

Our goal is to examine the effect of trade on growth. First, we use cross-section levels regressions, which are meant to capture the effect of openness on long-run growth. Second, we examine the effect of trade growth on income growth using decadal regressions, which will reflect medium-term changes. We instrument for trade, regulations, and institutions to adjust for the possibility that higher growth leads to institutional reform and more trade.

In the cross-sectional analysis, the dependent variable is the log-level of real per capita income. Under the assumption that in a distant past, incomes across countries were fairly similar, current levels of per capita income should reflect the varying growth performance of countries in the very long run. Figure 1a shows a scatter plot of trade openness and per-capita income in the three quarters of countries with the least regulations. The simple correlation between openness and income is positive and significant. Figures $1 \mathrm{~b}$ plots the same figure for the one-quarter most regulated countries, respectively. There are fewer observations when we restrict the sample so it is not surprising that the coefficient on openness is not significant in Figure 1b. But the magnitudes of the coefficients are of interest; in the most regulated economies there is no evidence that trade has a positive effect on growth. Figure 2 repeats the exercise using trade/GDP at PPP as the measure of openness. Again the evidence that openness affects growth is much less convincing among the most regulated economies. 
The figures suggest that the link between growth and openness is weaker or absent in the most regulated economies, but we have not controlled for the standard determinants of income. We do so by estimating the following equation:

$$
\text { Per-capita } \text { Income }_{i}=\beta_{0}+\beta_{1}(\text { TradeOpenness })_{i}+\beta_{2} \text { (TradeOpenness } * \text { Regulation }
$$
Dummy $_{i}+\beta_{3}(\text { Index of Regulations })_{i}+\beta_{4}(\text { Regulation Dummy })_{I}+\beta_{5}(\text { Population })_{i}+$ $\beta_{5}(\text { Landlocked })_{i}+\beta_{5}(\text { Distance to Equator })_{i}$.

where per capita income, trade, population and the regulation index enter in logs. The null hypothesis to be tested is that the effect of openness on growth is the same regardless of the degree of regulation. Thus, if the null is rejected then the coefficient on the interactive term between openness and the regulation index dummy $\left(\beta_{2}\right)$ will be significantly different from zero.

The Regulation dummy is a variable that is one if the country is among the most regulated economies. We define most regulated as the economies that rank in the top quarter of the sample according to our index..$^{5}$ We use a regulation dummy as opposed to the regulation index directly in the interaction because it offers the best fit and the interpretation is more straightforward. We also tried interacting the index directly with trade (after rescaling it to be increasing in simplicity). The signs are as expected but the significance is somewhat lower. Moreover, when both interactive terms (with the dummy and with the regulation index) are included in the regression equation, only the interactive with the dummy is significant, implying that there is a threshold after which the regulatory environment becomes less conducive to

\footnotetext{
${ }^{5}$ We also tried using one-fifth and one-third as cutoffs, the results were broadly similar, though tended to be somewhat stronger when the one-quarter cutoff was used. Loosening the threshold gives more degrees of freedom, but it also makes the sample more diverse in terms of regulations. We also tried using two cutoffs for bottom quarter and top quarter, but only the interactive with the bottom quarter is significant
} 
growth. In addition, we allowed for a quadratic effect, but again the dummy interactive performed best.

In line with some previous evidence, we expect that an increase in trade openness will promote growth. A better regulatory regime would increase growth through its effect on investment, productivity and new entry. ${ }^{6}$ Many papers rely on indicators of rule of law that are based on survey data. A problem with such perception-based indices is that they are likely to be tainted by stage of development. ${ }^{7}$ Still, as a robustness check we include the Kaufmann, Kraay and Zoido-Lobaton (2002) index in some of our regressions. Countries with a larger population and a larger market size are expected to grow faster because of scale economies. Countries that are land-locked and closer to the equator are expected to grow slower.

We first estimate Equation 1 with the log-level of real per capita income at PPP in 2000, in constant 1996 dollars (taken from the Summers-Heston dataset) as the dependent variable and openness measured using nominal trade/nominal GDP. Results are reported in Table 1. Column 1 reports the results including the regulation index but not the interactive term. All of the variables have the expected signs. We find that trade openness raises growth, but the coefficient is not significant. The results are similar to Rodrik et. al. (2002), who use rule of law in place of our index of regulations and also find no significant effect of openness on growth in crosssection regressions. The negative and significant coefficient on the regulation index implies that less regulated countries grow faster. ${ }^{8}$ Population has no significant effect on growth. ${ }^{9}$ Countries

\footnotetext{
${ }^{6}$ Using detailed panel data on entry regulations in Europe and the United Status, Alesina et al. (2002) find that entry regulation greatly reduces investment and is more important than privatization in doing so.

${ }^{7}$ See World Bank 2003 for an in depth discussion of the disadvantages of using perceptions based indicators.

${ }^{8}$ The reader is reminded that higher values on that index reflect more regulation.

${ }^{9}$ Alesina, Spolaore, and Wacziarg (2003) discuss the costs and benefits of size. While there are several positive effects of size, heterogeneity has negative effects on growth and is likely to be larger in bigger countries. Thus, it is not clear a larger size should be associated with higher income.
} 
further away from the equator grow significantly faster. Being landlocked hurts growth significantly.

The coefficient of interest is on openness in the most regulated economies. As shown in columns 2 , the coefficient is negative, highly significant, and more than three times as large as the coefficient on openness. This suggests that openness hinders growth in the most regulated countries. In addition, controlling for the detrimental effect of regulations on trade and growth, we find that the positive effect of trade on growth is more apparent. The coefficient on openness increases from .08 to .43 and is now significant at the 5 percent level. Summing the coefficient on openness and openness in the most regulated economies, implies that a 1 percent increase in openness in these highly regulated economies leads to about a 0.9 percent decrease ($1.33+0.43=-0.90)$ in income per capita.

In Column 3, we include rule of law as an additional variable and the coefficient on our regulation index goes down. This is expected as the rule of law index also reflects the institutional environment of countries. Countries with better-functioning institutions are less likely to be hampered with inefficient laws and regulations. Figure 5 confirms the very strong positive correlation between less regulation and stronger rule of law in our sample. When rule of law is included, the trade-regulation interactive term remains negative and highly significant.

In order to test whether our results are driven by a specific region, we include 7 regional dummies in the regression. ${ }^{10}$ The coefficient on the interactive term declines somewhat, but remains negative and highly significant. Even accounting for regional variation in growth, the effect of trade on highly regulated economies appears to be negative. The coefficient on

\footnotetext{
${ }^{10}$ Dummies are for East Asia and the Pacific, Eastern and Central Europe, Middle East and North Africa, South Asia, West Europe, North America (excluded), Sub Saharan Africa, and Latin America.
} 
openness declines markedly and is no longer significant, suggesting that to the extent that trade stimulated growth, its effects were highly regionalized.

Alcala and Ciccone (2002) argue that trade relative to GDP at PPP, which they call "real openness", is a better measure of openness than (nominal) trade to (nominal) GDP, while Rodrik and Rodriguez (2001) maintain that the reverse is true. The motivation for using real openness is that if trade raises productivity in the tradables sector, the price of non-tradables will rise and this can depress the measure of openness despite increased trade. However, as Rodrik and Rodriguez show, real openness may suffer a more extreme bias. If the tradable sector experiences a productivity gain for any non-trade reason, measured openness will increase, even if there is no increase in trade. Using real openness hence biases us toward accepting the relationship between openness and trade, even when one is absent.

Next, we use trade as a percent of GDP (adjusted for PPP) as the explanatory variable. The results are reported in Table 2. The results on trade are the same in sign though in this case as expected the evidence that openness promotes growth is much more robust. Even in the baseline regression model trade/GDP at PPP is significant (Column 1).

Column 2 reports the results with the interactive term. The interactive term remains negative and highly significant. Moreover, the coefficient is larger in magnitude than the coefficient on trade, implying that growth effects of trade are absent in highly regulated economies.

Columns 3 and 4 add the rule of law index and regional dummies, respectively. The coefficient on the interactive term remains negative and highly significant. However, as in the case of nominal openness, when regional variation is allowed for the growth effects of trade disappear. 


\section{Dealing with Endogeneity}

Next, we address the endogeneity problems in the OLS regressions. First, it is likely that countries that grow faster engage in more trade than others. Faster economic growth may lead to technological and production developments that expand export markets while domestic demand for imports may grow with rising incomes. This will lead us to over-estimate the effect of both trade and the interactive term on growth (in the sense that the coefficient on the trade-regulation interactive term is expected to be negative but its absolute magnitude is likely to be biased downward). There may also be omitted variables that are correlated both with per capita incomes and trade that will bias the coefficients on trade such as for instance factors like infrastructure or governance. Following Frankel and Romer (1999), we use the fitted values of trade predicted by the exogenous variables in a gravity model as an instrument for trade. ${ }^{11}$

Second, we instrument for the regulation index. Countries with rising or high incomes are more likely to face better regulatory environments. As countries grow faster, the costs of a heavy regulatory burden in the face of expanding markets and business opportunities becomes higher, thereby accelerating regulatory reform. The government may face greater pressures from the private sector to remove administrative constraints. We instrument for the regulation index with the share of population speaking English or a major European language as well as legal origin of countries. The premise is that colonial origin may have influenced the current regulatory state of countries by influencing their earlier institutional heritage. Legal origin may

\footnotetext{
${ }^{11}$ We use Frankel and Rommer's approach to get fitted bilateral trade shares (sum of imports and exports to GDP) for countries using 2000 bilateral trade data and we then aggregate the bilateral trade shares for each country $i$ across its trade partners $\mathrm{j}$. We use as instruments for bilateral trade shares geographical variables such as a dummy for landlocked countries, distance from equator, and other variables such as a dummy for a common border, language variables, population and cross-terms. See Frankel and Rommer (1999). In the case where we use trade/GDP at PPP (all in 1996 dollars) as the measure of openness, we also use as bilateral trade data sum of exports and imports to GDP at PPP (all in 1996 dollars).
} 
also determine the disposition of countries to reform their institutional structures as well as the pace of reforms. We do not use the measures of settler mortality as proposed by Acemoglu et al (2001) as this cuts our sample by more than a half.

Third, faster growth may also bring about improvements in the institutional environment. For instance, as countries grow faster, the level of education may improve and there may be a greater receptiveness for institutional improvements and reforms. In addition, the rule of law index is constructed from opinion surveys and other subjective measures. The responses of the experts engaged in the surveys may be biased by the current state of the economy. Also there are likely to be omitted variables correlated with both per capita real incomes and institutional quality in our regression such as political regime characteristics. We instrument here the rule of law index with the same variables as the regulation index.

Table 3 reports the results for openness. The first column repeats the corresponding OLS results (column 2, Table 1) for reference. First, we instrument only for the interactive term using predicted trade, the language variables, and legal origin as instruments. The coefficient on the interactive term increases (as does the coefficient on openness and the dummy) and remains negative and highly significant.

Column 3 reports the results using the same set of instruments, but instrumenting for openness, the regulation dummy, and the regulation index, as well as the interactive term. With the exception of openness, which is no longer significant, the sign and significance of all of the endogenous variables remains unchanged.

Column 4 reports the results using two stage instrumental variables. In the first stage, we regress the dummy and the interactive term on a selection of the excluded exogenous variables 
using logit and tobit respectively. ${ }^{12}$ The predicted values are used as instruments in the regression. Again, all of the instrumented variables except openness remain significant. In this case, there is less of a jump in the coefficient on the interactive term.

Using the same instruments, and instrumenting for rule of law as well as the other endogeneous variables leads to insignificant results for all the endogeneous variables. There are too many highly correlated endogenous variables to be identified by the same set of instruments. While all signs remain robust, none of the endogenous variables are significant (not reported). In the final column, the results are reported including rule of law, but assuming the regulation dummy variable is exogenous. ${ }^{13}$ Column 5 reports results of the same regression, excluding rule of law for comparison purposes. When rule of law is included, the regulation index is not significant. The trade interactive term remains highly significant.

While the IV results are supportive of the notion that trade does not support growth in highly regulated countries, it is very difficult to find good instruments that uniquely identify the endogenous variables. The lower half of Table 3 reports the Shea partial $\mathrm{R}^{2}$ and the P-value of the Hansen J-statistic for each regression. The Shea $\mathrm{R}^{2}$ takes into account the collinearity between the endogenous variables and also the extent to which the same instruments are being relied upon for identification. The Shea $\mathrm{R}^{2}$ is low for trade, indicating that part of the reason we may not get significant results for trade is that it is not well identified. Still, the highly significant results for the interactive term imply that any positive effect of trade on poorly regulated countries is highly suspect. The Hansen J-statistic tests the null hypothesis that the

\footnotetext{
${ }^{12}$ We use only a selection of the exogenous variables because it could not converge when all variables were included.

${ }^{13}$ In this case, in order to help identify the interactive term, we also add two instruments, an interaction between landlock and the dummy and between fraction of the population speaking European languages and the dummy.
} 
instruments are valid in an IV regression with robust standard errors. In all cases, we cannot reject that the instruments are valid.

Table 4 reports the results, using the same instruments as above except using real openness as the endogenous variable. In this case, there are two reasons why the coefficient on trade and the interactive term is likely to be biased upwards. First, countries that grow faster will have higher trade growth. Second, since trade is measured as a fraction of GDP at PPP, there are additional problems due to price effects. Columns 2-6 report the instrumented results. When we control for endogenous effects, the coefficient on trade increases in almost all cases and the coefficient on the interactive term remains negative and is larger in magnitude. The coefficient on the interactive term is always larger than the coefficient on openness, suggesting that trade does not enhance growth in highly-regulated economies. However, the coefficient on trade is no

longer robustly significant. In part, this is due to poor identification. The Shea partial $\mathrm{R}^{2}$ is quite low, especially in the last t column when rule of law is included. When we include rule of law, the interactive term remains highly significant and its magnitude is similar to OLS.

\section{Trade, Regulations and Growth in Recent Years}

The levels regressions provide evidence that long-run growth is not helped, and may even be hampered, by trade in highly regulated economies. However, it is possible that heavily regulated economies become more dependent on trade in the long run because of their inflexible domestic business environment, but that a higher level of trade in these economies is still associated with growth, or at least does not lead to an income loss. In this section, we examine changes in openness and income in the 1990s to see if the results are robust in the short/medium run. 
We carry out the data analysis using decadal growth rates. We estimate the following equation, which is essentially a lagged difference version of the levels regression equation (1) and includes initial income to control for convergence effects:

$$
y_{c t}-y_{c, t-k}=\alpha_{1} \cdot\left(y_{c, t-k}\right)+\alpha_{2}^{T} \cdot\left(X_{c t}-X_{c, t-k}\right),
$$

where $\mathrm{X}_{\mathrm{c}}$ is a set of control variables from equation 1 ( $t=$ time period; $k=$ number of lags). Equation (3) amounts to regressing growth on initial income and changes in the set of explanatory variables.

Ideally, we would like to estimate the growth regressions over three decades, as in Dollar and Kraay (2002). However, to do this we would need the one-quarter (or one-third) most regulated economies in each period, which is not available. As a result, we use only average growth the 1990s and continue to use the regulation data from Doing Business. This approach is valid, assuming that regulations are slow to change and have been roughly constant since 1990. We add the regulation index, a dummy variable for the most heavily regulated countries, and an interactive term between trade and the regulation dummy. Upon differencing over time, given the assumption of slow changes in regulations over time and a time invariant dummy variable, we end up with only the interactive term between the change in trade over time and the dummy variable as an additional explanatory variable to the decadal growth regressions. ${ }^{14}$

We extend the decadal panel dataset of Dollar and Kraay (2002), omitting the countries for which no data are available on regulations, legal origin and institutional measures, and considering only the 1990s. We end up with a maximum of 98 observations over the 1990 s. The list of countries is provided in the Appendix, Table A2.

\footnotetext{
${ }^{14}$ To the extent that the worst regulated countries are slow to grow, as a robustness check, we tried including the regulation dummy in the regression, it was very close to zero and never significant (not reported).
} 
First, we use the data on regulations and focus on the change in the last period. We regress the decadal average per capita GDP growth in the 1990s (measured at PPP in constant 1985 dollars $)^{15}$ on the initial value of $\log$ real GDP per capita at PPP (at constant 1985 dollars) at the beginning of the decade, the change over the previous decade in the log of average trade to GDP (or the log of average trade to GDP at PPP) ${ }^{16}$, the change in the average inflation rate, the change in the investment ratio, and the interactive term between the change in trade and the regulation dummy variable. ${ }^{17}$ In this section, because the sample is smaller and to keep the cutoff point similar to that from the cross-section regression, we report results for the one-third most regulated countries; the results are similar if we the one-quarter most regulated countries, though standard errors are slightly larger. We also try including a measure of the change in institutional environment. We use the average rule of law index from $\mathrm{ICRG}^{18}$ as an institutional measure. This measure reflects upon the security of property rights, risks of political instability and the stability of laws respectively. We also use the change in the number of revolutions and change in the fraction of the population killed in civil or international wars as alternative measures of institutional quality. ${ }^{19}$

In Table 5, estimation results are reported for the 1990s decadal regressions, using growth in trade/GDP as an independent variable. Columns 1-6 report results using OLS with a correction for heteroskedasticity. An increase in trade significantly raises growth. However, in

\footnotetext{
${ }^{15}$ The data here are not from the Summers-Heston dataset but taken from the Dollar and Kraay dataset. Dollar and Kraay use data on real per capita GDP at PPP at constant 1985 dollars from the Summers and Heston Penn World Tables Version 5.6, after extending it to the 1990s using constant price local currency growth rates.

${ }^{16}$ Trade/GDP is constructed by deflating the sum of exports and imports at constant 1995 dollars by the cumulative growth of US GDP deflator from 1985-1995 and dividing by GDP at PPP in constant 1985 dollars.

${ }^{17} \mathrm{We}$ also include change in government spending to GDP and change in the black market premium as additional measures of macro stability, but neither was ever significant, they tended to be close to zero and changed sign depending on specification, so we do not include them in the reported regressions.

${ }^{18}$ This is the Law and Order rating from ICRG and is different from the rule of law index of Kaufmann, Kraay, and Zoido-Lobaton (2002).

${ }^{19}$ The investment ratio is investment/GDP both at constant 1985\$, at PPP; the inflation measure is $\ln (1+$ inflation/100), inflation rate measured as annual percent change in CPI if available, otherwise annual percent change in GDP deflator. All data in the decadal analysis are from the Dollar and Kraay dataset.
} 
line with results from the previous section, we find that increased trade does not expand growth in heavily regulated economies, and the effect is also always significant. In contrast, the institutional measures are not significant, except for the ICRG index, which enters with the wrong sign.

Some regions have grown faster than others in recent years, owing in part to geographical idiosyncrasies that may be unrelated to trade and institutions. We add regional dummy variables to our growth regressions both to align our work with common empirical approaches (controlling for regional effects on growth) and as a robustness check. The coefficient on the interactive term is not significant when regional dummies are included — though its magnitude is very robustsuggesting that the slower growth in some economies may be due in part to regional effects (column 3).

To address endogeneity concerns due to omitted variables and feedback effects, we instrument for several of the variables in the regression. It is likely that income growth in the 1990s spurred trade growth. This would mean that both the coefficient on trade and the coefficient on the interactive term are likely to be too positive. To control for this potential feedback effect, we instrument for growth in trade for the 1990s with growth in trade over the previous decade (the 1980s), initial trade at start of the decade, and the black market premium at the start of the decade $(\ln (1+$ black market premium $))$. We instrument for the trade-regulation index dummy interactive term with the above-named instruments as well as the dummy for most regulated. We also instrument for the investment growth using lagged growth in investment.

Columns 7-9 in Table 5 report results with trade, the trade interactive term, and investment instrumented. The interactive term is less significant, though remains significant at the 10 percent level in all cases. The coefficient on openness is not significant when we 
instrument for investment and include regional dummies, however, the coefficient on the interactive term remains significant at the 10 percent level.

Next, we repeat the exercise using growth in the ratio of trade to GDP at PPP. The results are reported in Table 6. When the interactive term is not included (column 1) trade growth is not significant. However, when we include the interactive term (column 2), trade growth is positive and significant, while the interactive term is negative and significant. The coefficient on the interactive term is larger in magnitude than the coefficient on openness, implying that there has been no benefit from expanded trade in highly regulated economies in the 1990s. The results are very robust. We try including regional dummies (column 3), the institutional indices (column 4-6), and instrumenting for trade, the interactive term, and investment (columns 7-8) and the sign and significance of the coefficients remain similar. In the final column, we instrument for trade, the interactive term, and investment, as well as include regional dummies. In this case the significance of the coefficient on trade growth declines; the interactive term remains negative and highly significant.

The results from the growth regressions strongly support the levels regressions, confirming that greater openness is not conducive to income growth in highly regulated economies. One advantage of the growth regressions is that the instruments do a better job of explaining trade growth and the interactive term, than they do in the levels regressions.

\section{Conclusions}

Cross-country regressions suggest that increased trade is often good for growth. We show that this relationship breaks down in the most heavily regulated economies. Results from cross-sectional analysis imply that the effect of trade on growth in the long run is at best absent 
and at worst negative in heavily regulated countries. Results from decadal growth regressions confirm that trade does not stimulate growth in highly regulated economies.

The paper provides one answer to the question of what complementary policies are necessary for trade to benefit an economy. Our results imply that heavily regulated countries must improve their regulatory environment. The good news is that some of the steps are relatively easy. Governments can eliminate excess procedures for registering new businesses. The advent of new technologies, such as online registration, makes this an excellent time for countries to embark on this process. However, as is always the case with deregulation, difficulties will arise because of interest groups that stand to lose from a more flexible environment.

Our finding that trade might actually hamper growth in highly regulated countries warrants further research. One possibility is that in these inflexible economies, trade tends to expand in the wrong goods as countries grow, leading to immiserizing growth. The intuition follows directly from the theory of the second best. With one distortion in place (excessive regulation), reducing a second distortion (such as trade barriers or transport costs) need not make the country better off. If the regulatory environment severely distorts domestic prices then expanded trade can lead to lower income. This would be the case, for example, in an economy where regulations raise the price of manufactured goods and tariffs raise the price of agricultural goods. As tariffs come down and trade expands, production growth would primarily occur in the manufacturing sector, which could potentially lower welfare. Provided the world relative price of manufactured products is sufficiently below the domestic price, the value of output would fall as the share of production devoted to them expands. This is akin to Johnson's (1967) example of 
immiserizing growth, where growth in the face of a (tariff induced) price distortion leads to increased production of the good that the economy has a comparative disadvantage in producing.

An alternative explanation is that an increase in trade effectively wipes out domestic industry in highly regulated countries. Adjustment to a shock, such as increased openness, will take place very slowly in highly regulated economies. In a dynamic setting, it is possible that as other economies grow and relative prices change, a highly regulated economy is always too late—experiencing a string of shocks to which it never fully adjusts. 


\section{References}

Acemoglu D., S. Johnson, J. Robinson, 2001. "The Colonial Origins of Comparative Development: An Empirical Investigation" American Economic Review v91, n5 December: 1369-1401

Ades, A. and R. Di Tella, 1999."Rents, Competition, and Corruption” American Economic Review, 89, 4, 982-993.

Alcala, F. and A. Ciccone, 2001. "Trade and Productivity" CEPR Discussion Paper: 3095 December.

Alesina, A., E. Spolaore, and R. Wacziarg, 2003. "Trade, Growth and the Size of Countries." Harvard Institute of Economic Research discussion Paper 1995.

Alesina, A., S. Ardagna, G. Nicoletti, F. Schiantarelli, 2002. "Regulation and Investment" Harvard University, Mimer.

Ben David, D., 1993. "Equalizing Exchange Trade Liberalization and Income Convergence" Quarterly Journal of Economics 108(3), 653-79.

Bernard A. and B. Jensen, 1999. "Exporting and Productivity" NBER Working Paper \#7135.

Blanchard, O. and P. Portugal, 2001. "What Hides Behind the Unemployment Rate: Comparing Portuguese and U.S. Labor Markets" American Economic Review 91, 1, 187-207.

Botero, J., S. Djankov, R. La Porta, F. Lopez-de-Silanes, and A. Shleifer, 2003. “The Regulation of Labor" NBER Working Paper 9756.

Caselli F., G. Esquivel and F. Lefort, 1996. "Reopening the Convergence Debate: A New Look at Cross Country Growth Empirics" Journal of Economic Growth v1, n3 September: 363-89

Currie J. and A. Harrison, 1997. The Impact of Trade Reform on Capital and Labor in Morocco. Journal of Labor Economics 15(3), 44-71.

Djankov, S., R. La Porta, F. Lopez de Silanes, and A. Shleifer, 2002. "The Regulation of Entry" Quarterly Journal of Economics, 117, 1-37, February.

Djankov, S. and P. Murrell, 2002. "Enterprise Restructuring in Transition: A Quantitative Survey," Journal of Economic Literature, Vol. 40 (3) pp. 739-792.

Dollar, D. 1992. "Outward-Oriented Developing Countries Really Do Grow More Rapidly: Evidence from 95 LDCs, 1976-1985. Economic Development and Cultural Change, 40 (3), April, 523-544. 
Dollar, D. and A. Kraay, 2002. "Institutions, Trade and Growth" Paper prepared for the Carnegie-Rochester Conference Series on Public Policy.

Dollar D. and A. Kraay, 2003. "Institutions, Trade, and Growth: Revisiting the Evidence" World Bank Policy Research Working Paper 3004.

Fisman, R. and V. Sarria-Allende, 2004. "Regulation of Entry and the Distortion of Industrial Organization" Columbia University, Mimeo.

Frankel, J. and P. Romer, 1999. “Does Trade Cause Growth?” American Economic Review v89, n3 June: 379-99.

Johnson, H.G. 1967. "The Possibility of Income Losses from Increased Efficiency or Factor Accumulation in the Presence of Tariffs." Economic Journal, Chapter 22.

Kaufmann D., A. Kraay and P. Zoido-Lobaton, 2002. "Governance Matters from Measurement to Action" Finance and Development v37, n2 June: 10-13.

Klapper, L. Laeven, L. and R.Rajan, 2003. "Business Envoronment and Firm Entry: Evidence from International Data. Mimeo, World Bank.

Papageorgiou, D., M. Michaely and A. Choksi, eds., 1991. Liberalizing Foreign Trade. Cambridge, MA: Basil Blackwell Publishers for the World Bank, 7 volumes.

Pavcnik, N. 2002. "Trade Liberalization, Exit, and Productivity Improvements: Evidence from Chilean Plants,” The Review of Economic Studies 69, 245-76.

Redding S. 2002. “Specialization Dynamics” Journal of International Economics, 58, 299-334.

Revenga, A., 1997. "Employment and Wage Effects of Trade Liberalization: The Case of Mexican Manufacturing” Journal of Labor Economics, 15(3), S20-43.

Roberts, M. and J. Tybout, 1996. Industrial Evolution in Developing Countries. New York: Oxford University Press.

Rodrik D., A. Subramanian, and F. Trebbi, 2002 "Institutional Rule: The Primacy of Institutions over Geography and Integration in Economic Development" Mimeo, IMF.

Rodrik D., and F. Rodríguez, 2001. "Trade Policy and Economic Growth: A Skeptic's Guide to the Cross-National Evidence." Macroeconomics Annual 2000. Ed. Ben Bernanke and Kenneth S. Rogoff. MIT Press for NBER.

Sachs J. D. and Warner, A. 1995. "Economic Reform and the Process of Global Integration." Brookings Papers on Economic Activity, 1-118. 
Shea, J. 1996. "Instrument Relevance in Multivariate Linear Models: A Simple Measure." Technical Working Paper 193, NBER.

Wacziarg, R. and J. Wallack, 2003. "Trade Liberalization and Intersectoral Labor Movements." Forthcoming Journal of International Economics.

World Bank, 2003. Doing Business in 2004. World Bank and Oxford University Press. 
Figure 1: Cross-sectional (using current Trade/GDP)
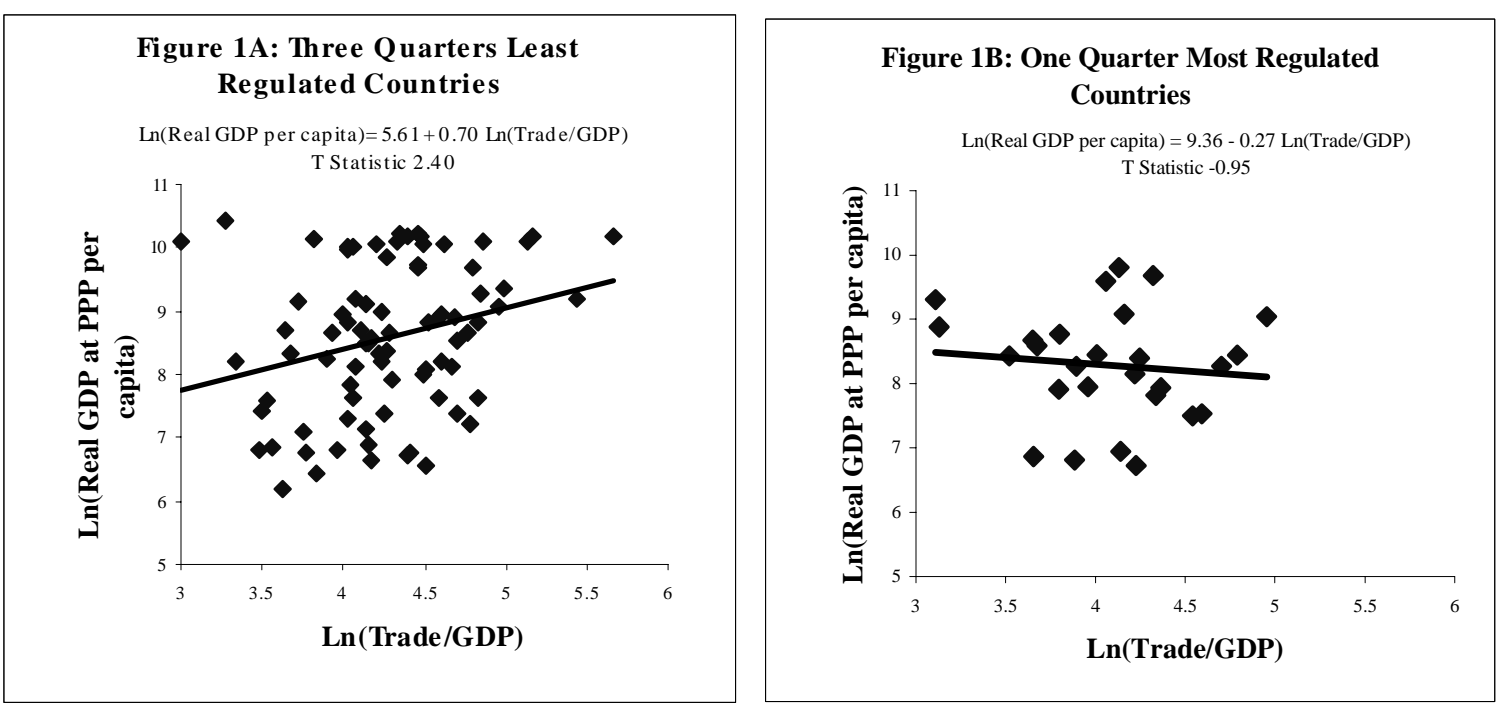

Figure 2: Cross-sectional (using Trade/GDP at PPP)
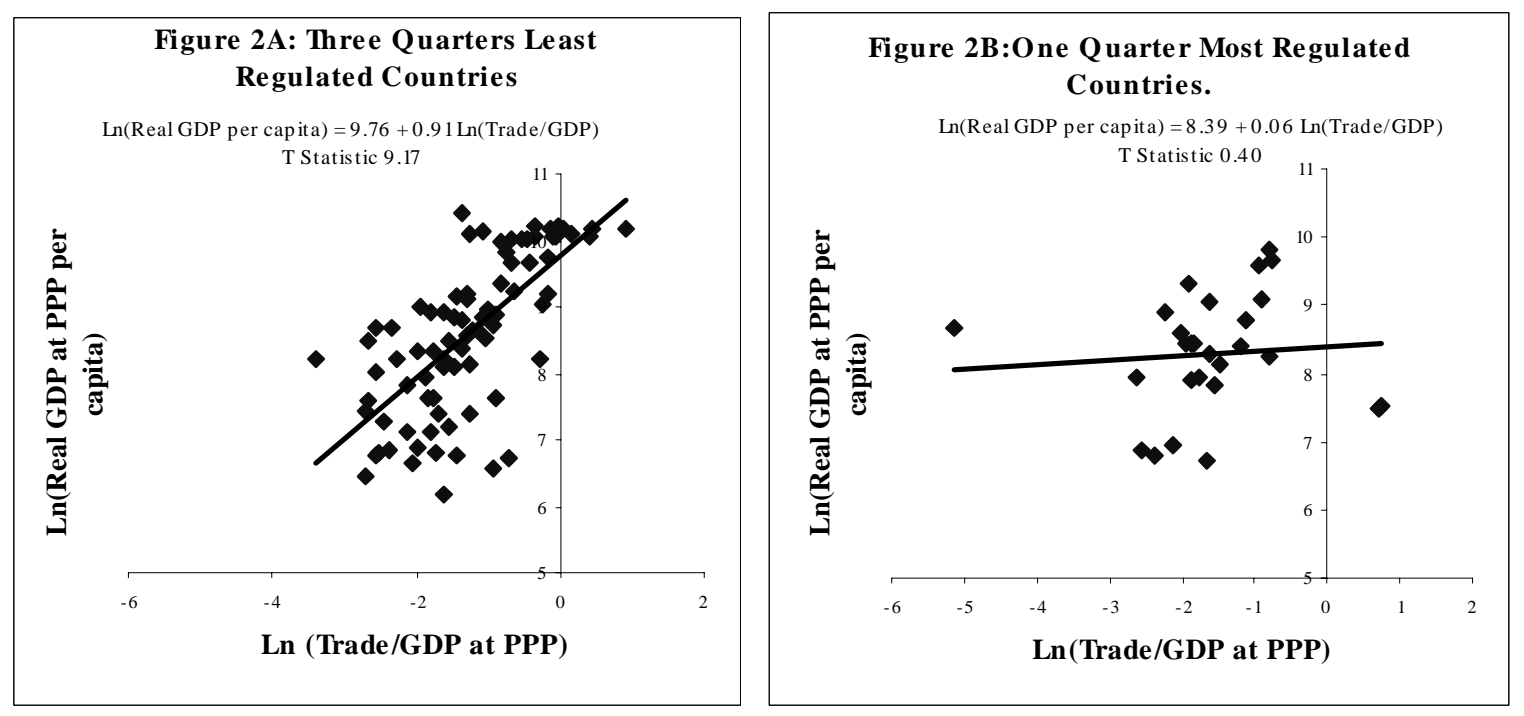
Figure 3: Growth (using current Trade/GDP)
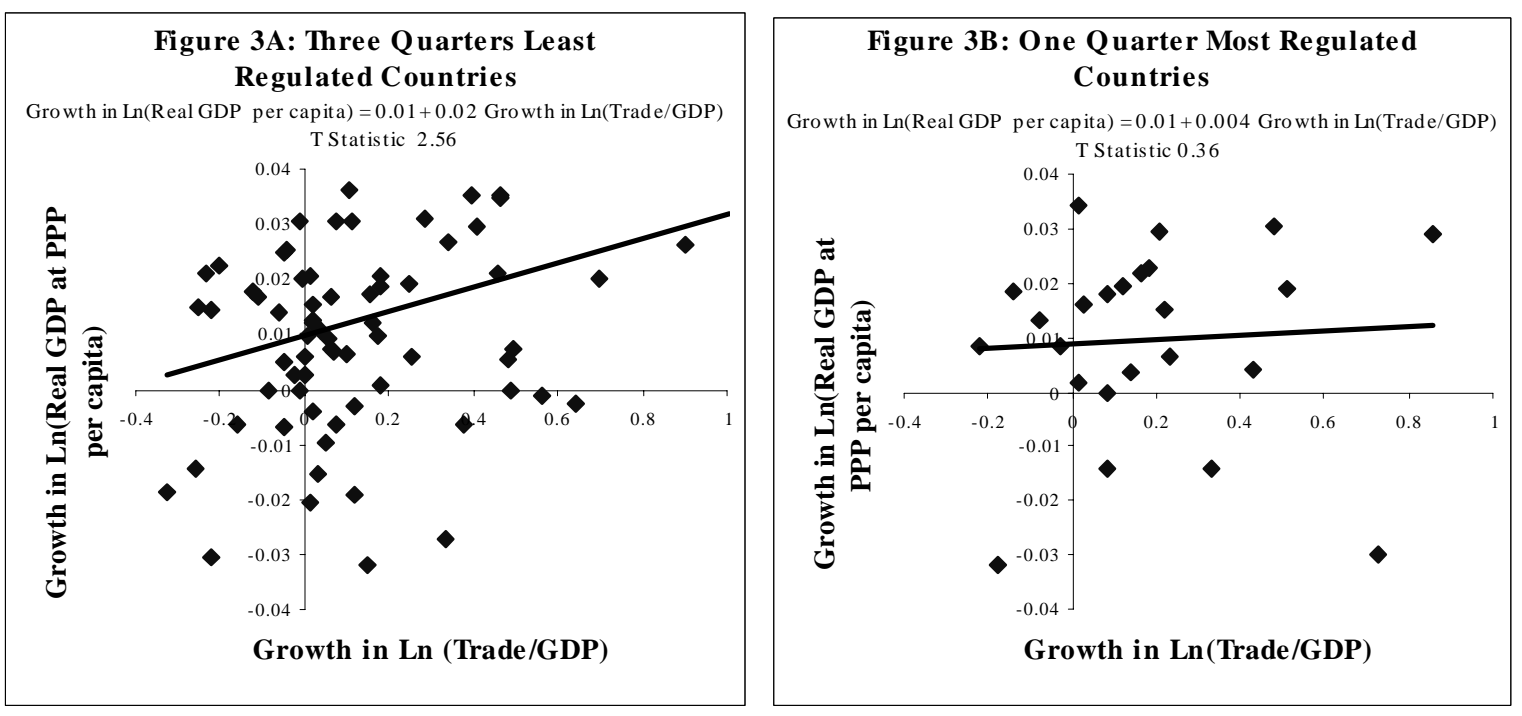

Figure 4: Growth (using Trade/GDP at PPP)
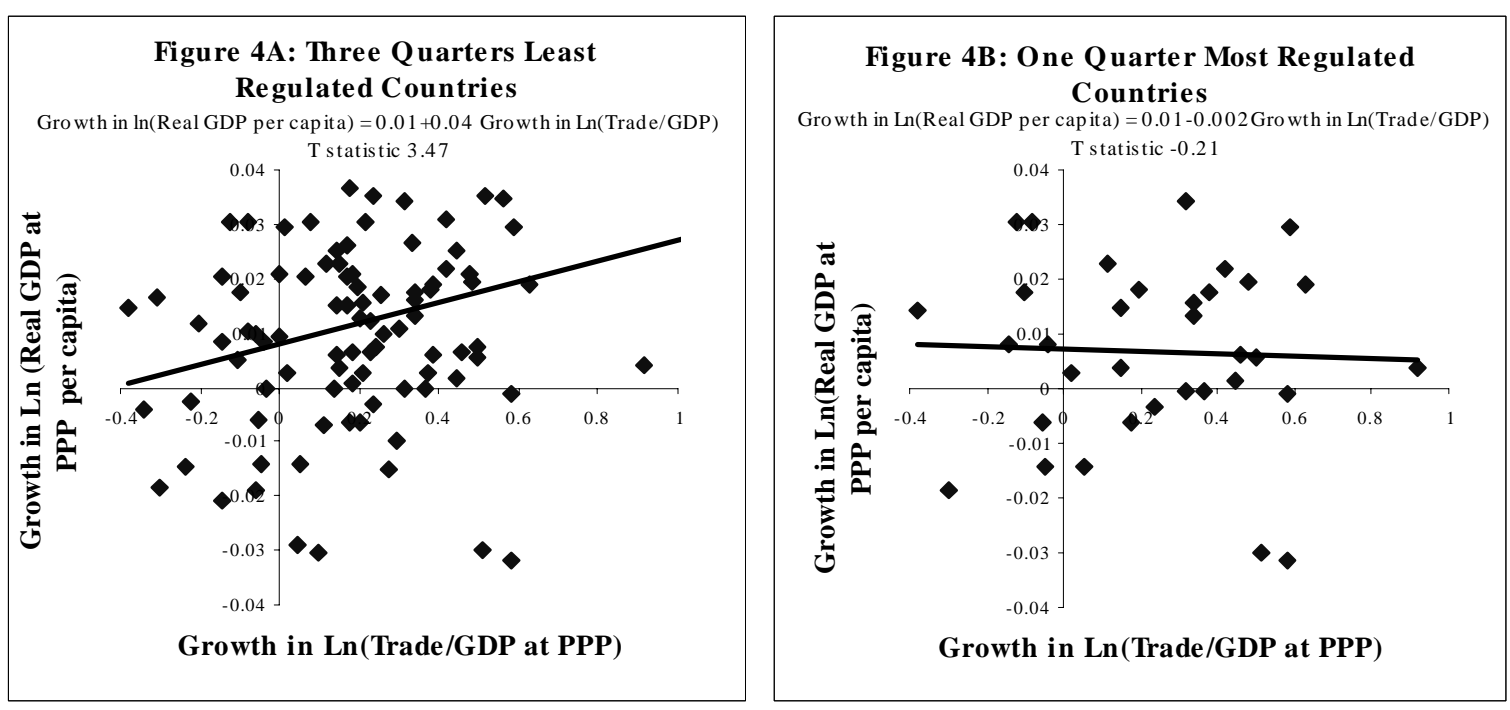
Figure 5: Rule of Law and Regulation Index

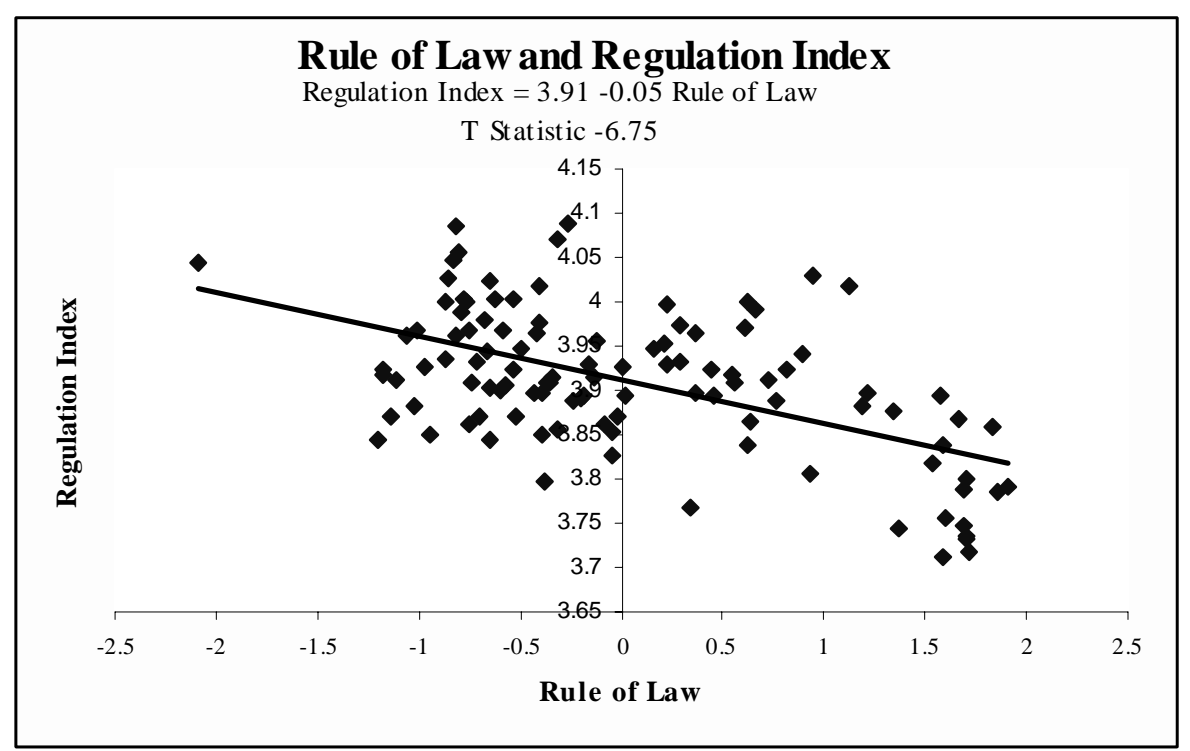




\section{Table 1: Cross-Sectional Estimation Results (Using Trade/GDP)}

\begin{tabular}{l|llll}
\hline \multirow{2}{*}{$\begin{array}{l}\text { Dependent Variable: Log real per } \\
\text { capita GDP 2000 (PPP) }\end{array}$} & \multicolumn{4}{|l}{ One-quarter worst regulated } \\
\cline { 2 - 5 } & $(1)$ & $(2)$ & $(3)$ & $(4)$ \\
\hline \multirow{2}{*}{ Ln (Trade/GDP) } & OLS & OLS & OLS & OLS \\
& 0.08 & 0.43 & 0.37 & 0.16 \\
Ln (Trade/GDP)*Regulation Index & $(0.41)$ & $(2.28)$ & $(2.53)$ & $(1.26)$ \\
Dummy Variable & -- & -1.33 & -1.13 & -0.80 \\
Composite Regulation Index & -2.37 & $(-3.72)$ & $(-3.07)$ & $(-2.17)$ \\
& $(-2.20)$ & -5.66 & -2.03 & -1.52 \\
Composite Regulation Index Dummy & $--4.99)$ & $(-1.63)$ & $(-1.29)$ \\
Variable & & 6.36 & 5.22 & 3.60 \\
Ln (Population) & 0.04 & $(4.33)$ & $(3.36)$ & $(2.28)$ \\
& $(0.65)$ & $(1.23)$ & $(1.94)$ & $(0.94)$ \\
Landlock & -0.56 & -0.50 & -0.26 & -0.08 \\
& $(-3.08)$ & $(-3.01)$ & $(-1.75)$ & $(-0.61)$ \\
Distance from Equator & 0.04 & 0.04 & 0.03 & 0.02 \\
& $(8.02)$ & $(10.00)$ & $(5.24)$ & $(2.06)$ \\
Rule of Law & -- & -- & 0.57 & 0.38 \\
& & & $(5.67)$ & $(2.79)$ \\
Intercept & 15.70 & 26.20 & 12.45 & 13.10 \\
& $(3.73)$ & $(5.86)$ & $(2.80)$ & $(3.17)$ \\
Region dummies* & $\mathrm{N}$ & $\mathrm{N}$ & $\mathrm{N}$ & $\mathrm{Y}$ \\
R -Squared & 0.53 & 0.64 & 0.73 & 0.80 \\
\# of Observations & 108 & 108 & 108 & 108 \\
\hline
\end{tabular}

Notes: Absolute value of t-statistics calculated with Huber/White/Sandwich-corrected standard errors are in parentheses.

* Dummies for East Asia and the Pacific, Eastern and Central Europe, Middle East and North Africa, South Asia, West Europe, North America (excluded), Sub Saharan Africa, and Latin America. 


\section{Table 2: Cross-Sectional Estimation Results (Using Trade/GDP at PPP)}

\begin{tabular}{l|llll}
\hline \multirow{2}{*}{$\begin{array}{l}\text { Dependent Variable: Log real per } \\
\text { capita GDP 2000 (PPP) }\end{array}$} & \multicolumn{4}{|l}{ One-quarter worst regulated } \\
\cline { 2 - 5 } & $(1)$ & $(2)$ & $(3)$ & $(4)$ \\
\hline \multirow{2}{*}{ Ln (Trade/GDP) } & OLS & OLS & OLS & OLS \\
& 0.34 & 0.55 & 0.30 & 0.03 \\
Ln (Trade/GDP)*Regulation Index & $(2.20)$ & $(4.84)$ & $(2.44)$ & $(0.23)$ \\
Dummy Variable & - & -0.71 & -0.64 & -0.54 \\
Composite Regulation Index & -1.45 & $(-4.29)$ & $(-4.35)$ & $(-3.74)$ \\
& $(-1.40)$ & -3.19 & -0.94 & -1.32 \\
Composite Regulation Index Dummy & $--2.70)$ & $(-0.75)$ & $(-1.14)$ \\
Variable & & -0.51 & -0.56 & -0.61 \\
Ln (Population) & 0.13 & $(-1.31)$ & $(-1.73)$ & $(-2.20)$ \\
& $(2.08)$ & $(2.29)$ & 0.09 & 0.03 \\
Landlock & -0.30 & -0.36 & -0.28 & $(0.66)$ \\
& $(-1.96)$ & $(-2.49)$ & $(-2.10)$ & $(-1.24)$ \\
Distance from Equator & 0.03 & 0.03 & 0.02 & 0.01 \\
& $(7.43)$ & $(7.44)$ & $(4.68)$ & $(1.32)$ \\
Rule of Law & -- & -- & 0.54 & 0.53 \\
& & & $(4.14)$ & $(4.01)$ \\
Intercept & 11.65 & 18.52 & 10.38 & 13.36 \\
& $(2.90)$ & $(4.05)$ & $(2.23)$ & $(3.28)$ \\
Region dummies* & $\mathrm{N}$ & $\mathrm{N}$ & $\mathrm{N}$ & $\mathrm{Y}$ \\
$\mathrm{R}$-Squared & 0.57 & 0.68 & 0.74 & 0.83 \\
\# of Observations & 108 & 108 & 108 & 108 \\
\hline See & & & & \\
\hline
\end{tabular}

See notes under Table 1. 


\section{Table 3: Cross-Section Analysis, Instrumental Variables}

(Using Trade/GDP)

\begin{tabular}{|c|c|c|c|c|c|c|}
\hline \multirow{2}{*}{$\begin{array}{l}\text { Dependent Variable: Log real } \\
\text { per capita GDP } 2000(P P P)\end{array}$} & \multicolumn{6}{|c|}{ One-quarter worst regulated } \\
\hline & (1) & $(2)^{A}$ & $(3)^{B}$ & $(4)^{C}$ & $(5)^{D}$ & $(6)^{D}$ \\
\hline & OLS & IV & IV & 2 SIV & IV & IV \\
\hline Ln (Trade/GDP) & $\begin{array}{l}0.43 \\
(2.38)\end{array}$ & $\begin{array}{l}1.23 \\
(3.66)\end{array}$ & $\begin{array}{l}0.91 \\
(1.07)\end{array}$ & $\begin{array}{l}-0.23 \\
(0.27)\end{array}$ & $\begin{array}{l}-0.19 \\
(-032)\end{array}$ & $\begin{array}{l}-0.08 \\
(-015)\end{array}$ \\
\hline Ln (Trade/GDP)*Regulation & -1.33 & -5.46 & -5.61 & -3.34 & -3.00 & -2.58 \\
\hline Index Dummy Variable & $(-3.72)$ & $(-3.18)$ & $(-2.02)$ & $(-2.03)$ & $(-2.63)$ & $(-2.58)$ \\
\hline Composite Regulation Index & $\begin{array}{l}-5.66 \\
(-4.99)\end{array}$ & $\begin{array}{l}-4.59 \\
(-2.98)\end{array}$ & $\begin{array}{l}-7.89 \\
(-2.35)\end{array}$ & $\begin{array}{l}-7.14 \\
(-3.41)\end{array}$ & $\begin{array}{l}-6.54 \\
(-4.93)\end{array}$ & $\begin{array}{l}-2.50 \\
(-1.30)\end{array}$ \\
\hline Composite Regulation Index & 6.36 & 23.31 & 24.98 & 14.85 & 13.24 & 11.21 \\
\hline Dummy Variable & $(4.33)$ & $(3.33)$ & $(2.10)$ & $(2.18)$ & $(2.76)$ & $(2.65)$ \\
\hline Ln (Population) & $\begin{array}{l}0.08 \\
(1.23)\end{array}$ & $\begin{array}{l}0.15 \\
(1.95)\end{array}$ & $\begin{array}{l}0.26 \\
(0.93)\end{array}$ & $\begin{array}{l}-0.05 \\
(-0.31)\end{array}$ & $\begin{array}{l}-0.04 \\
(-0.33)\end{array}$ & $\begin{array}{l}0.00 \\
(0.01)\end{array}$ \\
\hline Landlock & $\begin{array}{l}-0.50 \\
(-3.01)\end{array}$ & $\begin{array}{l}-0.54 \\
(-2.03)\end{array}$ & $\begin{array}{l}-0.44 \\
(-1.66)\end{array}$ & $\begin{array}{l}-0.53 \\
(-2.34)\end{array}$ & $\begin{array}{l}-0.53 \\
(-2.45)\end{array}$ & $\begin{array}{l}-0.32 \\
(-1.97)\end{array}$ \\
\hline Distance from Equator & $\begin{array}{l}0.04 \\
(10.00)\end{array}$ & $\begin{array}{l}0.05 \\
(7.53)\end{array}$ & $\begin{array}{l}0.05 \\
(5.55)\end{array}$ & $\begin{array}{l}0.05 \\
(7.20\end{array}$ & $\begin{array}{l}0.05 \\
(7.68)\end{array}$ & $\begin{array}{l}0.03 \\
(3.36)\end{array}$ \\
\hline Rule of Law & -- & -- & -- & -- & -- & $\begin{array}{l}0.53 \\
(2.30)\end{array}$ \\
\hline Intercept & $\begin{array}{l}26.20 \\
(5.86)\end{array}$ & $\begin{array}{l}17.29 \\
(6.44)\end{array}$ & $\begin{array}{l}25.25 \\
(2.11)\end{array}$ & $\begin{array}{l}33.54 \\
(5.50)\end{array}$ & $\begin{array}{l}33.94 \\
(5.66)\end{array}$ & $\begin{array}{l}17.52 \\
(2.38)\end{array}$ \\
\hline \multicolumn{7}{|l|}{$\begin{array}{l}\text { Shea partial } \mathrm{R}^{2} \text { of first-stage } \\
\text { regressions }\end{array}$} \\
\hline Ln (Trade/GDP) & & -- & 0.02 & 0.06 & 0.11 & 0.10 \\
\hline $\begin{array}{l}\text { Ln (Trade/GDP)*Regulation } \\
\text { Index Dummy Variable }\end{array}$ & & 0.12 & 0.04 & 0.10 & 0.25 & 0.23 \\
\hline Composite Regulation Index & & -- & 0.27 & 0.29 & 0.38 & 0.24 \\
\hline $\begin{array}{l}\text { Composite Regulation Index } \\
\text { Dummy Variable }\end{array}$ & & -- & 0.04 & 0.10 & -- & -- \\
\hline Rule of Law & & -- & -- & -- & -- & 0.18 \\
\hline Hansen overidentification test & & 5.77 & 3.00 & 7.24 & 11.22 & 8.49 \\
\hline$X^{2}(j) P-$ Value & & 0.45 & 0.39 & 0.06 & 0.13 & 0.20 \\
\hline $\mathrm{R}^{2}$ & 0.64 & 0.19 & 0.03 & 0.37 & 0.44 & 0.60 \\
\hline \# of Observations & 108 & 105 & 105 & 105 & 105 & 105 \\
\hline
\end{tabular}

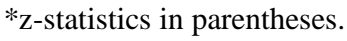

(A) Instrumented variables: Trade*Regulation Dummy. Instruments: predicted trade, fraction of the population speaking European language, fraction of the population speaking English, legal origin: British, French, Socialist, or German and included exogenous variables.

(B) Instrumented variables: Regulation Index, Regulation Dummy, Trade/GDP, Trade*Regulation Dummy. Instruments: predicted trade, fraction of the population speaking European language, fraction of the population speaking English, legal origin: British, French, Socialist, or German and included exogenous variables.

(C) Two Stage Instrumented variables: Regulation Index, Regulation Dummy, Trade/GDP, Trade*Regulation Dummy. Instruments: predicted trade, dumfit, tradedumfit, fraction of the population speaking European language, legal origin: British, French, or German, and excluded endogenous variables. Where dumfit is the fitted value of the dummy for $25 \%$ most regulated countries and tradedumfit is the fitted value of the interaction term. Dumfit and tradedumfit are estimated on the excluded exogenous variables using logit and tobit, respectively.

(D) Instrumented variables: Rule of Law (when included), Ln(Trade/GDP), Regulation Index, Trade*Regulation Dummy. Instruments: predicted trade, fraction of the population speaking European languages, fraction of the population speaking English, legal origin: British, French, or German, interactions between predicted trade and dummy, landlock and dummy, population and dummy, and between fraction of the population speaking European languages and dummy and excluded endogenous variables. 


\section{Table 4: Cross-Section Analysis, Instrumental Variables (Using Trade/GDP at PPP)}

\begin{tabular}{|c|c|c|c|c|c|c|}
\hline \multirow{2}{*}{$\begin{array}{l}\text { Dependent Variable: Log real } \\
\text { per capita GDP } 2000(P P P)\end{array}$} & \multicolumn{6}{|c|}{ One-quarter worst regulated } \\
\hline & (1) & $(2)^{A}$ & $(3)^{B}$ & $(4)^{C}$ & $(5)^{D}$ & $(6)^{D}$ \\
\hline & OLS & IV & IV & 2 SIV & IV & IV \\
\hline Ln (Trade/GDP) & $\begin{array}{l}0.55 \\
(4.84)\end{array}$ & $\begin{array}{l}0.89 \\
(3.65)\end{array}$ & $\begin{array}{l}0.89 \\
(2.54)\end{array}$ & $\begin{array}{l}1.00 \\
(2.90)\end{array}$ & $\begin{array}{l}0.67 \\
(3.07)\end{array}$ & $\begin{array}{l}0.28 \\
(0.72)\end{array}$ \\
\hline Ln (Trade/GDP)*Regulation & -0.71 & -1.70 & -1.80 & -1.62 & -0.88 & -0.78 \\
\hline Index Dummy Variable & $(-4.29)$ & $(-2.31)$ & $(-2.03)$ & $(-1.91)$ & $(-3.83)$ & $(-3.29)$ \\
\hline Composite Regulation Index & $\begin{array}{l}-3.19 \\
(-2.70)\end{array}$ & $\begin{array}{l}-1.59 \\
(-1.00)\end{array}$ & $\begin{array}{l}0.71 \\
(0.23)\end{array}$ & $\begin{array}{l}0.17 \\
(0.05)\end{array}$ & $\begin{array}{l}-1.61 \\
(-0.87)\end{array}$ & $\begin{array}{l}0.00 \\
(0.00)\end{array}$ \\
\hline Composite Regulation Index & -0.51 & -2.27 & -2.34 & -1.93 & -1.00 & -0.95 \\
\hline Dummy Variable & $(-1.31)$ & $(-1.80)$ & $(-1.24)$ & $(-1.06)$ & $(-1.93)$ & $(-2.05)$ \\
\hline Ln (Population) & $\begin{array}{l}0.13 \\
(2.29)\end{array}$ & $\begin{array}{l}0.15 \\
(2.28)\end{array}$ & $\begin{array}{l}0.14 \\
(1.53)\end{array}$ & $\begin{array}{l}0.18 \\
(2.05)\end{array}$ & $\begin{array}{l}0.14 \\
(1.93)\end{array}$ & $\begin{array}{l}0.06 \\
(0.63)\end{array}$ \\
\hline Landlock & $\begin{array}{l}-0.36 \\
(-2.49)\end{array}$ & $\begin{array}{l}-0.45 \\
(-2.39)\end{array}$ & $\begin{array}{l}-0.51 \\
(-1.68)\end{array}$ & $\begin{array}{l}-0.39 \\
(-1.39)\end{array}$ & $\begin{array}{l}-0.35 \\
(-2.06)\end{array}$ & $\begin{array}{l}-0.41 \\
(-2.70)\end{array}$ \\
\hline Distance from Equator & $\begin{array}{l}0.03 \\
(7.44)\end{array}$ & $\begin{array}{l}0.03 \\
(6.41)\end{array}$ & $\begin{array}{l}0.03 \\
(4.85)\end{array}$ & $\begin{array}{l}0.03 \\
(4.70)\end{array}$ & $\begin{array}{l}0.03 \\
(6.51)\end{array}$ & $\begin{array}{l}0.03 \\
(3.73)\end{array}$ \\
\hline Rule of Law & - & -- & - & - & - & $\begin{array}{l}0.44 \\
(1.02)\end{array}$ \\
\hline Intercept & $\begin{array}{l}18.52 \\
(4.05)\end{array}$ & $\begin{array}{l}12.50 \\
(2.04)\end{array}$ & $\begin{array}{l}9.13 \\
(0.77)\end{array}$ & $\begin{array}{l}5.17 \\
(0.40)\end{array}$ & $\begin{array}{l}12.49 \\
(1.69)\end{array}$ & $\begin{array}{l}7.12 \\
(0.88)\end{array}$ \\
\hline $\begin{array}{l}\text { Shea partial } \mathrm{R}^{2} \text { of first-stage } \\
\text { regressions }\end{array}$ & & & & & & \\
\hline Ln (Trade/GDP) & & -- & 0.12 & 0.14 & 0.15 & 0.05 \\
\hline $\begin{array}{l}\text { Ln (Trade/GDP)*Regulation } \\
\text { Index Dummy Variable }\end{array}$ & & 0.06 & 0.05 & 0.06 & 0.38 & 0.31 \\
\hline Composite Regulation Index & & -- & 0.21 & 0.19 & 0.33 & 0.22 \\
\hline $\begin{array}{l}\text { Composite Regulation Index } \\
\text { Dummy Variable }\end{array}$ & & -- & 0.05 & 0.06 & -- & -- \\
\hline Rule of Law & & -- & -- & -- & -- & 0.06 \\
\hline $\begin{array}{l}\text { Hansen overidentification test } \\
X^{2}(\mathrm{j}) \text { P-Value }\end{array}$ & & $\begin{array}{l}5.39 \\
0.37\end{array}$ & $\begin{array}{l}3.20 \\
0.20\end{array}$ & $\begin{array}{l}2.77 \\
0.43\end{array}$ & $\begin{array}{l}6.80 \\
0.34\end{array}$ & $\begin{array}{l}8.71 \\
0.12\end{array}$ \\
\hline $\begin{array}{l}\mathrm{R}^{2} \\
\text { \# of Observations }\end{array}$ & $\begin{array}{l}0.68 \\
108\end{array}$ & $\begin{array}{l}0.56 \\
105\end{array}$ & $\begin{array}{l}0.52 \\
105\end{array}$ & $\begin{array}{l}0.54 \\
105\end{array}$ & $\begin{array}{l}0.67 \\
105\end{array}$ & $\begin{array}{l}0.73 \\
105\end{array}$ \\
\hline
\end{tabular}

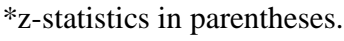

(A) Instrumented variables: Trade*Regulation Dummy. Instruments: predicted trade, fraction of the population speaking English, legal origin British, French, Socialist, or German and included exogenous variables.

(B) Instrumented variables: Regulation Index, Regulation Dummy, Trade/GDP, Trade*Regulation Dummy. Instruments: predicted trade, fraction of the population speaking English, legal origin British, French, Socialist, or German and included exogenous variables.

(C) Two Stage Instrumented variables: Regulation Index, Regulation Dummy, Trade/GDP, Trade*Regulation Dummy. Instruments: predicted trade, dumfit, tradedumfit, legal origin British, French, Socialist, or German, and excluded endogenous variables. Where dumfit is the fitted value of the dummy for $25 \%$ most regulated countries and tradedumfit is the fitted value of the interaction term. Dumfit and tradedumfit are estimated on the excluded exogenous variables using logit and tobit, respectively.

(D) Instrumented variables: Rule of Law (when included), Ln(Trade/GDP), Regulation Index, Trade*Regulation Dummy. Instruments: predicted trade, fraction of the population speaking English, legal origin: British, French, Socialist, or German, interactions between predicted trade and dummy, landlock and dummy, population and dummy, and excluded endogenous variables. 


\section{Table 5: Growth Analysis (Using Trade/GDP)}

\begin{tabular}{|c|c|c|c|c|c|c|c|c|c|}
\hline \multicolumn{10}{|c|}{$\begin{array}{c}\text { Dependent Variable: Decadal average real per capita GDP growth }(P P P) \\
\text { One-third worst regulated }\end{array}$} \\
\hline & (1) & $(2)$ & (3) & (4) & (5) & (6) & (7) & $(8)$ & (9) \\
\hline & OLS & OLS & OLS & OLS & OLS & OLS & $\mathrm{IV}^{\mathrm{A}}$ & $\mathrm{IV}^{\mathrm{A}}$ & $\mathrm{IV}^{\mathrm{A}}$ \\
\hline $\begin{array}{l}\text { Change over previous decade in } \\
\text { average Ln (Trade/GDP) }\end{array}$ & $\begin{array}{l}0.02 \\
(3.56)\end{array}$ & $\begin{array}{l}0.03 \\
(3.78)\end{array}$ & $\begin{array}{l}0.02 \\
(3.23)\end{array}$ & $\begin{array}{l}0.03 \\
(3.75)\end{array}$ & $\begin{array}{l}0.03 \\
(3.41)\end{array}$ & $\begin{array}{l}0.04 \\
(3.98)\end{array}$ & $\begin{array}{l}0.06^{*} \\
(1.79)\end{array}$ & $\begin{array}{l}0.06^{*} \\
(2.09)\end{array}$ & $\begin{array}{l}0.01 * \\
(0.42)\end{array}$ \\
\hline $\begin{array}{l}\text { Change over previous decade in } \\
\text { average Ln (Trade/GDP) X } \\
\text { Composite regulation index } \\
\text { dummy variable }\end{array}$ & -- & $\begin{array}{l}-0.02 \\
(-2.12)\end{array}$ & $\begin{array}{l}-0.02 \\
(-1.45)\end{array}$ & $\begin{array}{l}-0.02 \\
(-1.89)\end{array}$ & $\begin{array}{l}-0.02 \\
(-2.17)\end{array}$ & $\begin{array}{l}-0.03 \\
(-2.53)\end{array}$ & $\begin{array}{l}-0.05^{*} \\
(-2.13)\end{array}$ & $\begin{array}{l}-0.05^{*} \\
(-1.86)\end{array}$ & $\begin{array}{l}-0.08^{*} \\
(-1.71)\end{array}$ \\
\hline $\begin{array}{l}\text { Initial log real per capita income at } \\
\text { start of previous decade }\end{array}$ & $\begin{array}{l}0.005 \\
(3.92)\end{array}$ & $\begin{array}{l}0.005 \\
(3.89)\end{array}$ & $\begin{array}{l}0.005 \\
(1.59)\end{array}$ & $\begin{array}{l}0.01 \\
(3.91)\end{array}$ & $\begin{array}{l}0.01 \\
(3.88)\end{array}$ & $\begin{array}{l}0.01 \\
(3.52)\end{array}$ & $\begin{array}{l}0.01 \\
(4.23)\end{array}$ & $\begin{array}{l}0.01 \\
(4.14)\end{array}$ & $\begin{array}{l}0.001 \\
(0.15)\end{array}$ \\
\hline $\begin{array}{l}\text { Change over previous decade in } \\
\text { average inflation rate }\end{array}$ & $\begin{array}{l}-0.03 \\
(-6.65)\end{array}$ & $\begin{array}{l}-0.02 \\
(-5.46)\end{array}$ & $\begin{array}{l}-0.02 \\
(-4.69)\end{array}$ & $\begin{array}{l}-0.02 \\
(-5.54)\end{array}$ & $\begin{array}{l}-0.02 \\
(-5.27)\end{array}$ & $\begin{array}{l}-0.02 \\
(-5.96)\end{array}$ & $\begin{array}{l}-0.03 \\
(-3.85)\end{array}$ & $\begin{array}{l}-0.03 \\
(-3.78)\end{array}$ & $\begin{array}{l}-0.03 \\
(-2.57)\end{array}$ \\
\hline $\begin{array}{l}\text { Change over previous decade in } \\
\text { average investment/GDP at PPP } \\
\text { Change over previous decade in } \\
\text { average institutional measure: }\end{array}$ & $\begin{array}{l}0.07 \\
(1.97)\end{array}$ & $\begin{array}{l}0.07 \\
(1.93)\end{array}$ & $\begin{array}{l}0.06 \\
(1.71)\end{array}$ & $\begin{array}{l}0.07 \\
(1.90)\end{array}$ & $\begin{array}{l}0.08 \\
(2.02)\end{array}$ & $\begin{array}{l}0.06 \\
(1.41)\end{array}$ & $\begin{array}{l}0.05 \\
(1.45)\end{array}$ & $\begin{array}{l}0.06^{*} \\
(0.88)\end{array}$ & $\begin{array}{l}0.003^{*} \\
(0.04)\end{array}$ \\
\hline Revolutions & -- & -- & -- & $\begin{array}{l}0.001 \\
(0.18)\end{array}$ & -- & -- & -- & -- & -- \\
\hline $\begin{array}{l}\text { Fraction of population killed in } \\
\text { wars }\end{array}$ & -- & -- & -- & -- & $\begin{array}{l}-0.58 \\
(-0.82)\end{array}$ & -- & -- & -- & -- \\
\hline ICRG law and order & -- & -- & -- & -- & -- & $\begin{array}{l}-0.004 \\
(-2.07)\end{array}$ & -- & -- & -- \\
\hline Intercept & $\begin{array}{l}-0.03 \\
(-3.03)\end{array}$ & $\begin{array}{l}-0.03 \\
(-3.00)\end{array}$ & $\begin{array}{l}-0.04 \\
(-1.34)\end{array}$ & $\begin{array}{l}-0.04 \\
(-3.06)\end{array}$ & $\begin{array}{l}-0.04 \\
(-3.04)\end{array}$ & $\begin{array}{l}-0.04 \\
(-2.73)\end{array}$ & $\begin{array}{l}-0.05 \\
(-3.19)\end{array}$ & $\begin{array}{l}-0.05 \\
(-3.19)\end{array}$ & $\begin{array}{l}0.003 \\
(0.07)\end{array}$ \\
\hline Regional dummies & $\mathrm{N}$ & $\mathrm{N}$ & $\mathrm{Y}$ & $\mathrm{N}$ & $\mathrm{N}$ & $\mathrm{N}$ & $\mathrm{N}$ & $\mathrm{N}$ & $\mathrm{Y}$ \\
\hline \multicolumn{10}{|l|}{$\begin{array}{l}\text { Shea partial } R^{2} \text { of first-stage } \\
\text { regressions }\end{array}$} \\
\hline Ln (Trade/GDP) & -- & -- & -- & -- & -- & -- & 0.12 & 0.13 & 0.12 \\
\hline $\begin{array}{l}\text { Ln (Trade/GDP)*Regulation } \\
\text { Index Dummy Variable }\end{array}$ & -- & -- & -- & -- & -- & -- & 0.25 & 0.24 & 0.13 \\
\hline $\begin{array}{l}\text { Change over previous decade in } \\
\text { average investment/GDP at PPP }\end{array}$ & -- & -- & -- & -- & -- & -- & -- & 0.38 & 0.36 \\
\hline Hansen overidentification test & -- & -- & -- & -- & -- & -- & 4.14 & 4.06 & 2.78 \\
\hline $\mathrm{X}^{2}(\mathrm{j})$ P-Value & -- & -- & -- & -- & -- & -- & 0.13 & 0.13 & 0.25 \\
\hline $\begin{array}{l}\mathrm{R}^{2} \\
\# \text { of Observations }\end{array}$ & $\begin{array}{l}0.38 \\
98\end{array}$ & $\begin{array}{l}0.41 \\
98\end{array}$ & $\begin{array}{l}0.48 \\
98\end{array}$ & $\begin{array}{l}0.41 \\
96\end{array}$ & $\begin{array}{l}0.42 \\
93\end{array}$ & $\begin{array}{l}0.42 \\
82\end{array}$ & $\begin{array}{l}0.33 \\
85\end{array}$ & $\begin{array}{l}0.30 \\
85\end{array}$ & $\begin{array}{l}0.26 \\
85\end{array}$ \\
\hline
\end{tabular}

Notes: Absolute value of t-statistics calculated with Huber/White/Sandwich-corrected standard errors are in parentheses.

Regional dummies are as listed in Table 1. Asterisks denote variables instrumented.

A: Sets of instruments are: lagged decadal change in $\ln$ (Trade/GDP), initial trade at start of the same decade, initial ln (1+black market premium rate) at start of same decade, lagged growth in investment (only when investment is instrumented) and regulation index dummy variable and exogenous variables in regression. 
Table 6: Growth Analysis

(Using Trade/GDP at PPP)

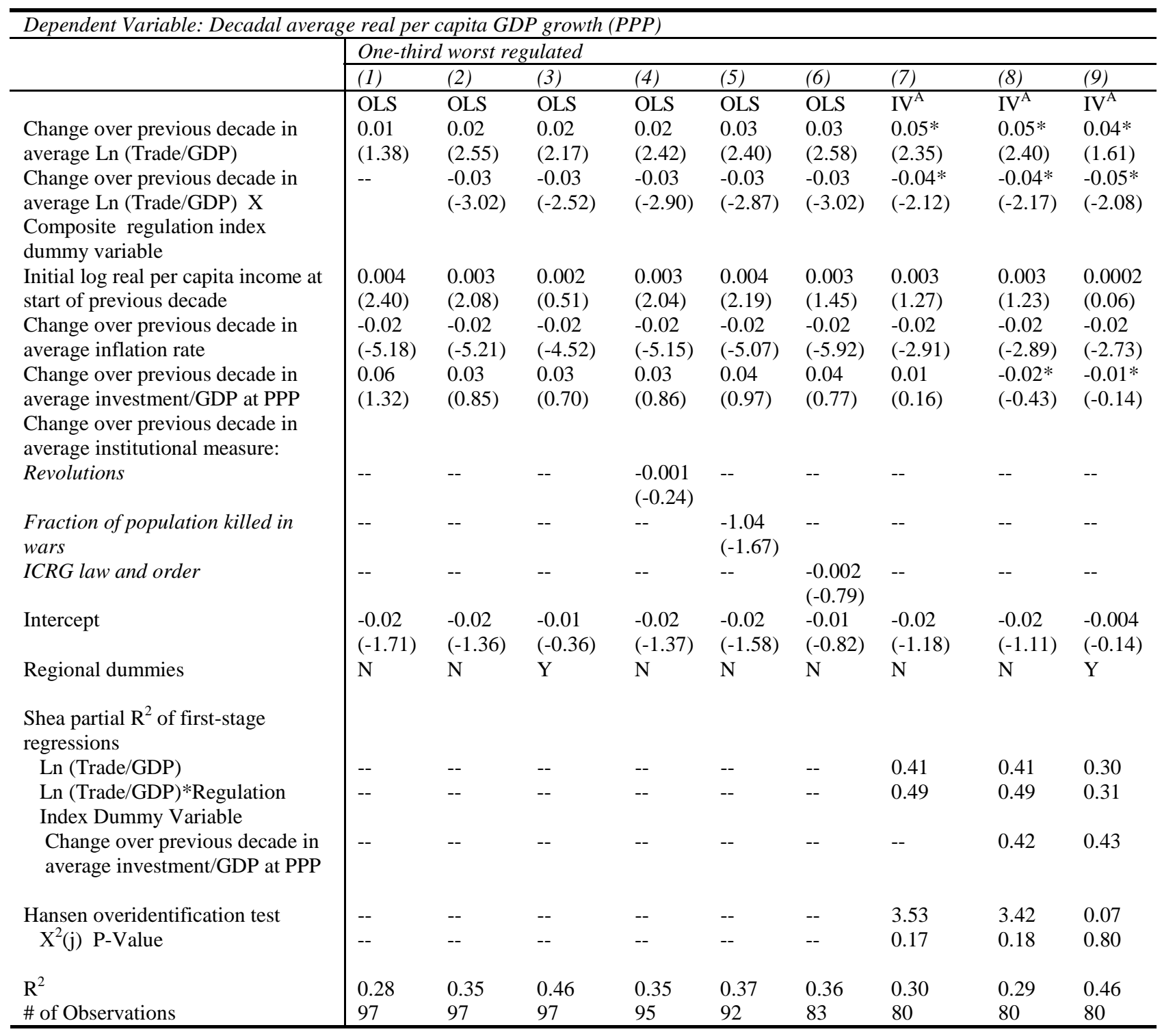

See notes under Table 5. 


\section{Appendix}

Table A1: List of Countries in Cross-sectional Analysis

\begin{tabular}{|c|c|c|c|}
\hline Albania & Dominican Republic & Korea Republic. & Portugal \\
\hline Algeria & Ecuador & Kyrgyz Republic & Romania \\
\hline Argentina & Egypt & Latvia & Russian Federation \\
\hline Armenia & El Salvador & Lebanon & Rwanda \\
\hline Australia & Ethiopia & Lesotho & Senegal \\
\hline Austria & Finland & Lithuania & Slovak Republic \\
\hline Azerbaijan & France & Macedonia & Slovenia \\
\hline Bangladesh & Georgia & Madagascar & South Africa \\
\hline Belarus & Germany & Malawi & Spain \\
\hline Belgium & Ghana & Malaysia & Sri Lanka \\
\hline Benin & Greece & Mali & Sweden \\
\hline Bolivia & Guatemala & Mexico & Switzerland \\
\hline Brazil & Guinea & Moldova & Syrian Republic \\
\hline Bulgaria & Honduras & Morocco & Tanzania \\
\hline Burkina Faso & Hong Kong & Mozambique & Thailand \\
\hline Cameroon & Hungary & Nepal & Togo \\
\hline Canada & India & Netherlands & Tunisia \\
\hline Chad & Indonesia & New Zealand & Turkey \\
\hline Chile & Iran & Niger & Uganda \\
\hline China & Ireland & Nigeria & Ukraine \\
\hline Colombia & Israel & Norway & United Kingdom \\
\hline Congo Dem Rep. & Italy & Pakistan & United States of America \\
\hline Costa Rica & Jamaica & Panama & Uruguay \\
\hline Cote D'Ivoire & Japan & Paraguay & Venezuela \\
\hline Croatia & Jordan & Peru & Yemen \\
\hline Czech Republic & Kazakhstan & Philippines & Zambia \\
\hline Denmark & Kenya & Poland & Zimbabwe \\
\hline
\end{tabular}

Note: The one-quarter most heavily regulated countries are highlighted in italics. In order of degree of highest regulation the top fifteen in this sample are: Brazil, Belarus, Mozambique, Venezuela, Paraguay, Congo Dem, Portugal, Chad, El Salvador, Bolivia, Spain, Azerbaijan, Peru, Ukraine and Colombia. There are 108 countries in the sample. 
Table A2: List of Countries in Growth Analysis

\begin{tabular}{|l|l|l|l|}
\hline Algeria & Egypt & Lao & Portugal \\
\hline Angola & El Salvador & Lesotho & Rwanda \\
\hline Argentina & Ethiopía & Madagascar & Senegal \\
\hline Australia & Finland & Malawi & Slovak Republic \\
\hline Austria & France & Malaysia & South Africa \\
\hline Bangladesh & Germany & Mali & Spain \\
\hline Belgium & Ghana & Mauritania & Sri Lanka \\
\hline Benin & Greece & México & Sweden \\
\hline Bolivia & Guatemala & Mongolia & Switzerland \\
\hline Brazil & Guinea & Morocco & Syrian Republic \\
\hline Bulgaria & Haiti & Mozambique & Taiwan \\
\hline Burkina Faso & Honduras & Namibia & Thailand \\
\hline Botswana & Hong Kong & Nepal & Togo \\
\hline Cameroon & Hungary & Netherlands & Tunisia \\
\hline Canada & India & New Zealand & Turkey \\
\hline Chad & Indonesia & Nicaragua & Uganda \\
\hline Chile & Iran & Niger & United Kingdom \\
\hline China & Ireland & Nigeria & United States of America \\
\hline Colombia & Israel & Norway & Uruguay \\
\hline Congo Republic. & Italy & Pakistan & Venezuela \\
\hline Costa Rica & Jamaica & Panama & Vietnam \\
\hline Cote D'Ivoire & Japan & Papua New Guinea & Zambia \\
\hline Denmark & Jordan & Paraguay & Zimbabwe \\
\hline Dominican Republic & Kenya & Peru & \\
\hline Ecuador & Korea Republic. & Philippines & \\
\hline
\end{tabular}

There are 98 countries in the OLS sample using current trade as listed above. However in the sample for trade at PPP, Bulgaria, Germany, Hong Kong, Lao and Mongolia are excluded but Macedonia, Poland, Romania and Tanzania are included. 
Table A3: Tables of Correlation Coefficients

(Cross-sectional Sample)

\begin{tabular}{|c|c|c|c|c|}
\hline & $\begin{array}{l}\text { Rule of } \\
\text { Law }\end{array}$ & $\begin{array}{c}\text { Log } \\
(\text { Trade/GDP) }\end{array}$ & $\begin{array}{l}\text { Log real per capita } \\
\text { income (PPP } \\
\text { constant 1996\$) }\end{array}$ & $\begin{array}{c}\text { Composite } \\
\text { Regulation Index }\end{array}$ \\
\hline Rule of Law & 1 & & & \\
\hline Log (Trade/GDP) & 0.24 & 1 & & \\
\hline $\begin{array}{l}\text { Log real per capita } \\
\text { income (PPP constant } \\
1996 \$)\end{array}$ & 0.77 & 0.22 & 1 & \\
\hline $\begin{array}{l}\text { Composite Regulation } \\
\text { Index }\end{array}$ & -0.55 & -0.19 & -0.37 & 1 \\
\hline No of Observations & 108 & & & \\
\hline
\end{tabular}

\begin{tabular}{|c|c|c|c|c|}
\hline & $\begin{array}{l}\text { Rule of } \\
\text { Law }\end{array}$ & $\begin{array}{c}\text { Log }(\text { Trade/GDP } \\
\text { at PPP) }\end{array}$ & $\begin{array}{l}\text { Log real per capita } \\
\text { income (PPP } \\
\text { constant } 1996 \$)\end{array}$ & $\begin{array}{c}\text { Composite } \\
\text { Regulation Index }\end{array}$ \\
\hline Rule of Law & 1 & & & \\
\hline $\begin{array}{l}\text { Log (Trade/GDP at } \\
\text { PPP) }\end{array}$ & 0.69 & 1 & & \\
\hline $\begin{array}{l}\text { Log real per capita } \\
\text { income (PPP constant } \\
1996 \$)\end{array}$ & 0.77 & 0.54 & 1 & \\
\hline $\begin{array}{l}\text { Composite Regulation } \\
\text { Index }\end{array}$ & -0.55 & -0.39 & -0.37 & 1 \\
\hline No of Observations & 108 & & & \\
\hline
\end{tabular}


Table A4: Descriptive Statistics of the Regulation Index by Income Group and Region (in natural logarithms)

\begin{tabular}{|l|r|r|r|}
\hline Income Group & \multicolumn{1}{|l|}{ Mean } & $\begin{array}{l}\text { Standard } \\
\text { Deviation }\end{array}$ & \multicolumn{1}{l|}{ Number } \\
\hline Low Income & 3.93 & 0.06 & 35 \\
\hline Lower Middle & 3.94 & 0.07 & 32 \\
\hline Upper Middle & 3.92 & 0.07 & 16 \\
\hline High & 3.84 & 0.09 & 25 \\
\hline Overall & 3.91 & 0.08 & 108 \\
\hline Region & & & 10 \\
\hline East Asia \& Pacific & 3.85 & 0.10 & 22 \\
\hline Europe and Central Asia & 3.93 & 0.05 & 12 \\
\hline Middle East and North Africa & 3.92 & 0.06 & 5 \\
\hline South Asia & 3.88 & 0.04 & 25 \\
\hline Sub-Saharan Africa & 3.92 & 0.06 & 18 \\
\hline Latin American \& Caribbean & 3.97 & 0.07 & 14 \\
\hline Western Europe & 3.84 & 0.08 & 2 \\
\hline North America & 3.72 & 0.02 & \\
\hline
\end{tabular}

Note: Income group classification is according to World Bank Classification. Higher values on the regulatory index amount to more regulation. The entire Doing Business sample as at January 2004 consists of 133 countries. The series for number of entry procedures, number of days and employment laws index over these 133 countries were rescaled so that the mean of each series equaled 50 and the standard deviation 5 . The regulation index $=$ $0.5^{*} \ln ($ entry index $)+0.5 * \ln ($ labor employment laws index $)$ where $\ln ($ entry index $)=\ln (0.5 *$ number of entry procedures $+0.5^{*}$ number of days). The labor employment laws index is itself an equal weighted average of the flexibility of hiring index, conditions of employment index and flexibility of firing index. The regulation index ranges in value from 3.71 to 4.09 . 